\title{
Fyziologické hormonální reakce u novorozence
}

\author{
MUDr. Lenka Ratzenbeková, MUDr. Simona Kontul'ová, MUDr. Petra Borůvková, MUDr. Jiří Havránek \\ Dětské a novorozenecké oddělení, Nemocnice Slaný
}

Klíčová slova: Halbanova reakce, galaktorea, fluor albus, novorozenecké akné.

Key words: neonatal mastauxe, galactorrhea, fluor albus, acne neonatorum.

V praxi, at' už na novorozeneckém oddělení nebo $v$ ordinacích PLDD, se můžeme setkat s hormonálními reakcemi u novorozenců. Jedná se o jevy fyziologické, způsobené přechodem mateřských hormonů z matky na plod během těhotenství.

Jedním z těchto jevů je tzv. Halbanova reakce - zduření prsních žláz (Obr. 1 - reakce prsní žlázy, v okolí olupujíci se kůže). Fyziologická velikost mléčné žlázy u novorozence je $1 \mathrm{~cm}$ v průměru, vlivem estrogenů se může zvětšit až na 3-4cm. Není vázána na pohlaví, může se vyskytnout jak u děvčátek, tak u chlapců a bývá pozorována jak bilaterálně, tak i unilaterálně. Také se můžeme setkat se slabou sekrecí mléka z mléčné žlázy, tzv. novorozeneckou galaktoreou, která se označuje také jako neonatální mléko nebo witch's milk (mléko čarodějnic). Název je odvozen z období kolem 17. století, kdy se tradovalo, že čarodějnice spícím novorozencům mléko odebíraly a používaly jej ve své magii. Zahraniční literatura uvádí, že se s neonatálním mlékem můžeme setkat u 5\% donošených nebo hraničně donošených novorozenců. Halbanova reakce je jev přechodný, může přetrvávat i několik týdnů, zpravidla vymizí do 2 měsíců a nevyžaduje žádnou léčbu. Nedoporučují se masáže ani jiné pokusy o vyprázdnění žlázy, které by mohly vést k rozvoji mastitidy s lokálním zarudnutím a horečkou, v horším případě až k tvorbě abscesu.

Další hormonální reakcí je výtok z pochvy u děvčátek (Obr. 2). Ten může být hlenovitý -
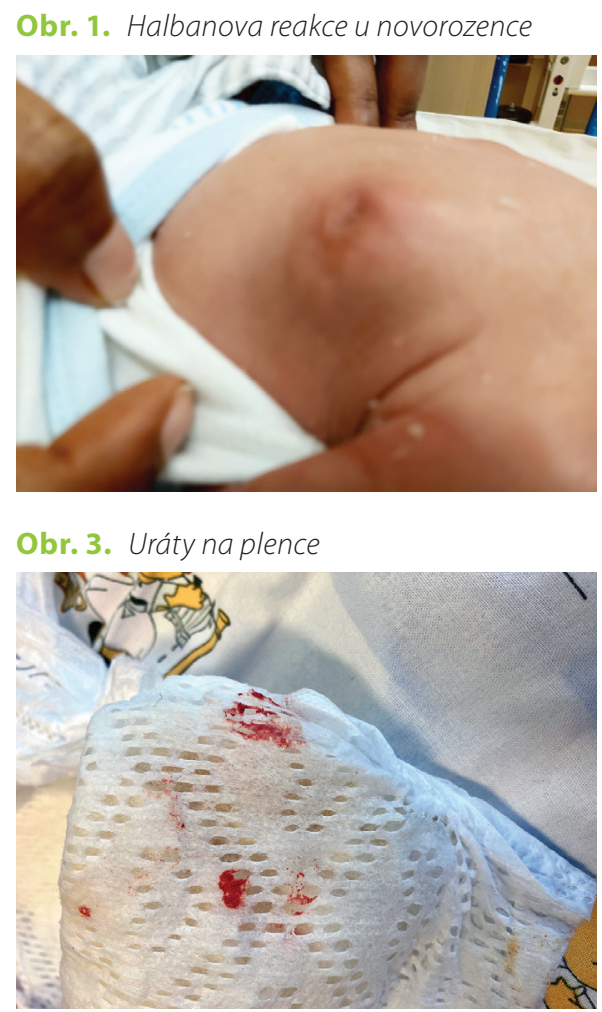

fluor albus, ale i krvavý - tzv. pseudomenstruace. Výtok zpravidla mizí do několika dnů po narození. Matky často považují za krvácení prítomnost urátů na plence, které jsou zbarvené do oranžovočervena (Obr. 3). Jedná se však o soli kyseliny močové, jejichž vylučování je $v$ řádech dnů po narození fyziologické.

V souvislosti s pưsobením hormonů se u novorozenců můžeme setkat také s acne neonatorum (Obr. 4). Objevuje se asi u $20 \%$ fyziologických novorozenců - časteji u chlapců,
Obr. 2. Vaginální výtok novorozence

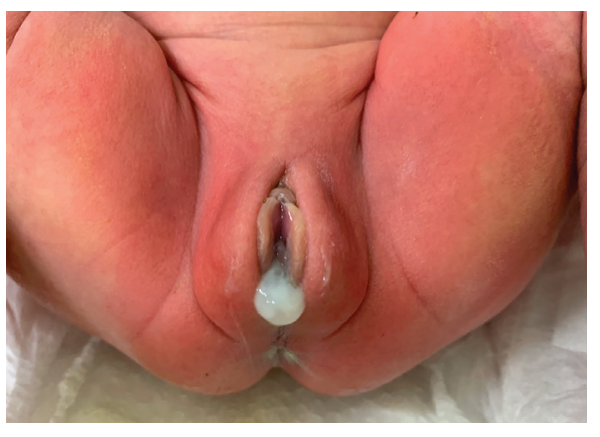

Obr. 4. Acne neonatorum (prevzato z www.atlasdermatologico.com)

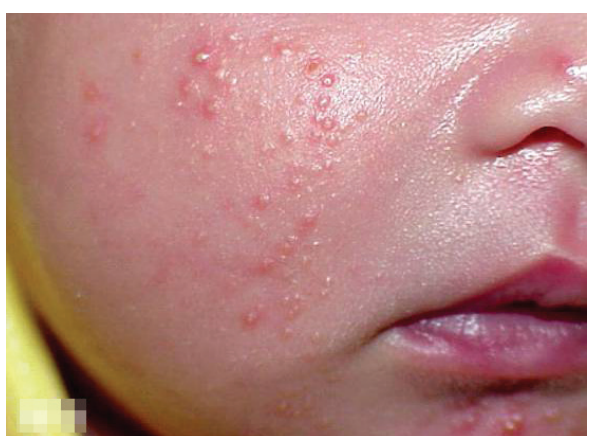

a to v prvních týdnech života. Vzniká vlivem jak mateřských, tak neonatálních androgenů, a také v důsledku zvýšené citlivosti androgenních receptorů mazových žláz. Pro acne neonatorum je typický nález malých červených papul a pustul objevujících se predominantně na čele a tvářích, může přecházet do kštice. Nemusí vést k výskytu těžkého akné vulgaris v pubertě. Léčba není nutná, spontánně vymizí s ústupem hormonů v prvních 3-4 měsících po narození - po období minipuberty. 